\title{
Implementasi Metode Algoritma Genetika Untuk Menentukan Penjadwalan Pelajaran Di SMKN 1
}

\author{
Yuliana $^{1}$, Vivi Nur Alaeyda ${ }^{2}$ \\ Fakultas Ilmu Komputer, Program Studi Sistem Informasi \\ Universitas Darwan Ali \\ yuliana08016@gmail.com
}

\begin{abstract}
Abstrak
Menentukan jadwal pelajaran merupakan suatu hal yang sangat penting dalam kegiatan mengajar. Dengan memiiki jadwal pelajaran yang tepat maka guru yang mengajar serta siswa dapat menjalani pelajaran dengan baik. Oleh karena itu guru maupun siswa memerlukan penjadwalan yang baik agar tidak terjadi bentrok antara pelajaran yang satu dengan pelajaran yang lainnya. Nah dalam kasus tersebut maka sangat diperluknnya sistem algoritma yang baik yaitu dengan menggunakan sistem algoritma genetika yang dapat membantu meringankan kesulitan penjadwalan tersebut. Metode ini lebih memudahkan kita melakukan penjadwalan dibandingkan metode konvensional. Dengan kita menerapkan metode ini untuk kedapannya maka akan sangat membantu kita untuk melakukan penjadwalan pelajaran disekolah SMKN 1 yang lebih efektif dan dan tapat.
\end{abstract}

\section{Kata kunci: Algoritma Genetika, Penjadwalan Pelajaran.}

\begin{abstract}
Determining a lesson schedule is very important in teaching activities. By having the right lesson schedule, teachers who teach and students can undergo lessons well. Therefore, teachers and students need fair scheduling to have no clash between one class and another. In this case, a suitable algorithm system is required, namely by using a genetic algorithm system that can help alleviate scheduling difficulty. This method makes scheduling more comfortable than conventional methods. Applying this method to its practicality will significantly help us schedule lessons at SMKN 1, which is more effective and accurate.
\end{abstract}

Keywords: Genetic Algorithm, Lesson Scheduling.

\section{PENDAHULUAN}

Penjadwalan pembelajaran merupakan suatu hal yang sangat penting, kegitan ini termasuk dalam sebuah proses mengajar. Terkadang disetiap sekolah terdapat bentrokan terhadap jam pelajaran yang lainnya, sedangkan kita harus meleksanakan pelajaran dengan waktu yang tepat agar dapat bejalan lancar. Untuk membuat jadwal pelajaran tidaklah mudah kita harus melihat dari berbagai aspek yang dapat mempengaruhi penjadwalan tersebut. Menetukan penjadwalan ini merupakan sebuah kegitan yang sangat penting dan menjadi prioritas terhadap guru dan siswa. Dalam pembuatan penjadwalan pelajaran ini kita harus memilahguru berdasarkan keahliannya dan untuk menentukan waktunya kita harus memperhatikan pelajaran yang lain apakahn terdapat

Tumpukan pelajaran sebelumnya kepada siswa. Salah satu solusi dari masalah ini adalah membuat penjadwalan pelajarn yang efektif dan baik dengan menggunakan algoritma genetika yang merupakan salah satu cara yang tepat untuk digunakan menyelesaikan masalah tersebut. Dibandingkan menggunakan 
metode konvensional, metode algorima genetika ini jauh lebih mudah untuk menyelesaikan masalah penjadwalan ini

\section{Tujuan Penelitian}

Penelitian ini bertujuan untuk membantu permasalahan yang sering terjadi saat melakukan penjadwalan pembelajaran, Serta dapat meminimalisir human error.

\section{Tinjauan Pustaka}

Algoritma Genetika (GA) pertama kali pertama kali diciptakan oleh John Holland dari Universitas Michigan (1975). Penemuan algoritma genetika terinspirasi dari teori evolusi Darwin. Algoritma buatan Holland adalah metode untuk memindahkan satu populasi lain dengan menggunakan seleksi alam bersama dengan operator genetik lainnya seperti crossover, dan mutasi. Crossover menukar bagian dari dua kromosom, meniru rekombinasi biologis diantara dua organisme "single chromosom". Mutasi secara random mengubah nilai gen pada beberapa lokasi yang ada didalam kromosom. Variasi pada suatu kromosom akan mempengaruhi reproduksi dan tingkat kemampuan organisme untuk tetap hidup.

Terdapat beberapa tahapan dari algoritma genetika yaitu:

1. Inisialisasi Kromosom

Inisialisasi dilakukan untuk membangkitkan himpunan solusi baru secara acak/random yang terdiri atas sejumlah string chromosome dan ditempatkan pada pen ampungan yang disebut populasi (Mahmudy, 2015). Representasi kromosom dapat menggunakan bilangan biner, bilangan integer, real coded, maupun permutasi.

2. Crossover merupakan operasi yang bekerja untuk menggabungkan 2 kromosom induk menjadi kromosom baru. Jumlah solusi jadwal yang mengalami crossover ditentukan oleh parameter crossover rate. Metode crossover yang paling umum digunakan adalah metode one-cut-point, yang secara acak memilih satu titik potong dan menukarkan bagian kanan dari tiap induk untuk menghasilkan offspring (Mahmudy, 2015).

3. Mutasi dilakukan dengan memilih satu induk secara acak dari populasi. Metode mutasi yang digunakan adalah dengan memilih satu titik acak kemudian mengubah nilai gen pada titik tersebut. Metode mutasi yang paling sederhana adalah reciprocal exchange mutation. Metode ini bekerja dengan memilih dua posisi (exchange point / XP) secara random kemudian menukarkan nilai pada posisi tersebut (Mahmudy, 2015). Selain itu juga terdapat metode insertion exchange mutation.

4. Evaluasi adalah fungsi yang digunakan untuk mengetahui ketahanan kromosom masih pantas diteruskan eksistensinya (Tyas, Rahman, \& Dewi, 2013). Setelah itu dihitung nilai fitness yang merepresentasikan nilai suatu inidividu. Jurnal Pengembangan Teknologi Informasi dan Ilmu Komputer 458 Fakultas Ilmu Komputer, Universitas Brawijaya Semakin besar nilai fitness maka semakin baik individu tersebut. 5. Seleksi Proses terakhir dalam algoritma genetika adalah seleksi yaitu memilih individuindivide terbaik berdasarkan nilai fitness yang telah dihasilkan. Metode seleksi ada metode seleksi elitism, binary tournament dan roulette wheel selection

\section{LANDASAN TEORI}

Menurut Asle Montagu ilmu pengetahuan dalam bukunya the cultured man yaitu suatu pengetahuan yang dapat disusun dalam satu tempat atau sistem yang berasal dari pengalaman, proses pembelajaran dan percobaan yang telah 
dilakukan dan hasilnya dapat dipakai untuk menentukan hakikat prinsip tentang hak yang sedang dipelajari.

Ilmu mempunyai sebuah objek yang bisa didapatkan sendiri dan bersifat kajian yang terdiri dari suatu golongan masalah sama baik sifat serta hakikatnya, tampak dari luar ataupun bentuknya dari dalam. Objek kajiannya dapat bersifat ada, karena masih harus diuji dulu keberadaannya.

Begitupun juga dengan pengetahuan yang dapat dicari atau dipelajari oleh sesama manusia hasil dari usaha mencari definisi alam semesta, ilmu jenis tidak mempunyai kepastian, jadi dapat berubah entah itu bertambah ataupun akan berkurang sesuai kebutuhan zamannya ataupun hasil riset penemuan manusia sebagai makhluk yang berakal.

\section{METODE PENELITIAN}

Jenis data

Terdapat dua jenis data, yaitu primer dan skunder:

1) Data primer, yaitu data yang didapat secara lansung dari penelitian

2) Data skunder, yaitu data yang didapat dari data yang sudah ada

Teknik mengumpul data

1) melakukan studi Pustaka studi Pustaka yaitu suatu metode pengumpulan data dengan melihat laporan studi yang sudah ada sebelumnya.

2) Observasi

Metode ini dilakukan dengan melakukan pengamatan secara lansung

3) Wawancara

Wawancara yaitu sebuah proses tanya jawab terhadap pihak yang terkait

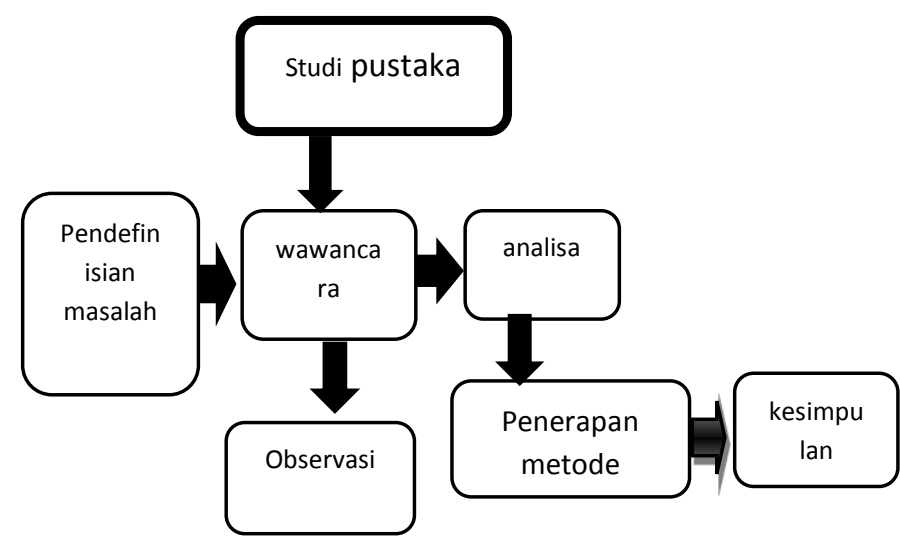

Gambar 1. Alur Penelitian

\section{IMPLEMENTASI DAN PEMBAHASAN}

\section{Analisa Permasalahan}

sistem penjawalan pelajaran yang ada disekolah menengah kejuruan (SMKN) 1 mungkin sudah bisa dikatakan baik. Namun, masih terdapat ketidak efektifan dengan aplikasi penjadwalan sekolah tersebut karena setiap guru dan mata pelajaran belum mempunyai database sendiri. Masih terdapat kekurangan dan sering terjadi human eror saat melalukan input data oleh pihak kurikulum. Masalah ini disebabkan oleh banyaknya data guru yang mengajar yang harus dimasukan kedalam aplikasi Microsoft excel secara manual. Saat ingin melihat jadwal pelajaran para guru dikasih kertas jadwal pelajaran atau ditempelkan dimading sekolah agar dapat mengetahui jadwalnya masingmasing. Padahal pembutan jadwal pelajaran sudah menggunakan computer hanya saja computer tersebut hnaya digunakan untuk membuat dan menyimpan data. Nah oleh karena itu maka dibutuhkannya pengembangan suatu penjadwalan pelajaran yang dapat mengatasi kekurangan dari masalah tersebut.

\section{Analisis sistem}


disekolah SMKN1 merupakan sekolah yang cukup favorit didaerah setempat. Di sekolah SMKN1 kegiatan mengajar dilaksanakan dari senin-sabtu, pada hari senin dimulai pukul 06.30 sampai 15.00 dan hari selasa-sabtu dimulai pukul 06.45 sampai 15.00. dalam sehari di sekolah ini ada 2 kali istirahat yaitu pada pukul 09.30 dan pukul 11.30. dalam seminggu jumlah jam mengajar diSMK tersebut adalah 24 jam. Guru mengampu mata pelajaran yang sudah ditentukan. Penerapan metode algoritma ini bertujuan untuk pengumpulan data yang dibutuhkan sebagai input, untuk membuat aplikasi penjadwalan pelajaran dengan metode algoritma genetika adalah guru, mata pelajaran guru,mata pelajaran, ruang, waktu,dan kelas.

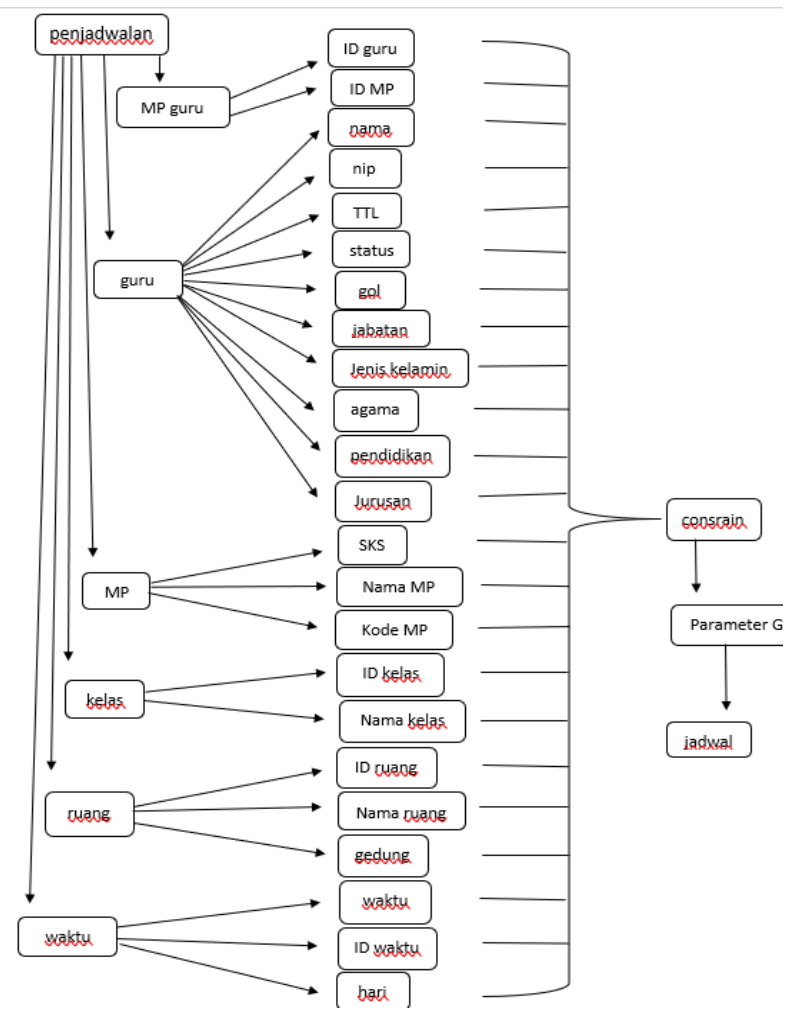

Gambar 2. Analisa Sistem analisa ini dapat menunjukkan bahwa ada aspek-aspek dalam memperluaskan penjadwalan mengajar diantaranya yaitu menganalisa user dan data dalam mengajar yang akan nantinya digunakan untuk menghitung algoritma genetika.

Desain Umum Sistem Gambar diatas menjelaskan ilustrasi umum sebagai desain sistem penjadwalan mengajar menggunakan rumus algoritma genetika tersebut. Tahap awal di mulai dengan menginput dari data MP guru sampai data waktu, lalu dilakukan dengan lanjutan data akan diproses menggunakan perhitungan algoritma genetika dan akan menghasilkan output penjadwalan mengajar

bentuk output Penjadwalan mengajar di SMKN 1 sangat di perlukan oleh jam lajar-mengajar setiap minggu nya, jumlah mata pelajaran yang akan disesuaikan dengan kurikulum, jumlah ruang kelas yang ada disesuaikan dan jumlah guru yang mengajar dalam suatu mata pelajaran. Kurikulum yang ada di SMKN 1 ini bahwa jumlah jam pelajaran atau mengajar dalam 24 jam seminggu itu tidak termasuk jam ekstrakurikuler.

Sehingga mata pelajaran ini akan diberlakukan mulai hari senin sampai jumat dengan maksimal satu jam pelajaran dalam waktu 40 menit. Proses pembelajaran akan dimulai sejak jam 07.00 sampai jam 15.00 wib rentang waktu pembelajaran ini hanya berlaku I hari senin sampai kamis. Di hari jumat proses waktu pembelajaran sama dimulai pada pukul 07.00, tapi berakhir pukul 11.15.

Tabel 1. Jadwal

\section{Analisa Dalam Kebutuhan Non Fungsional}




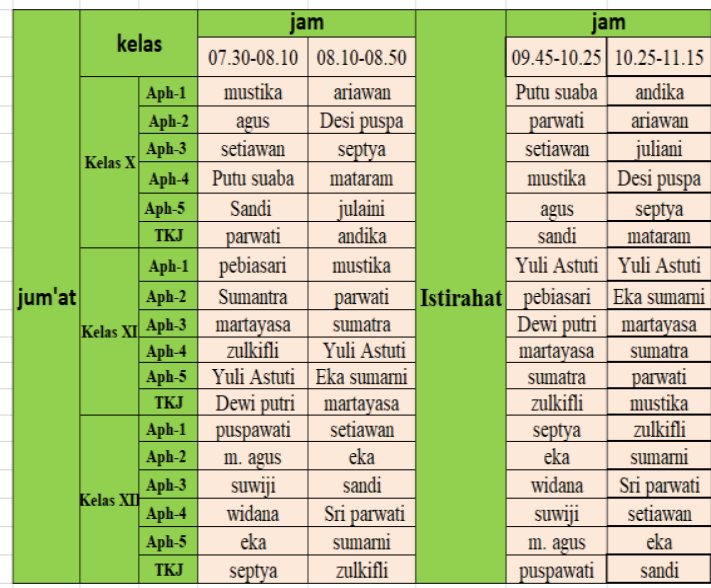

Masalah terbesar yang akan dihadapi oleh guru adalah ketersediaan tenaga guru masing-masing mata pelajaran untuk mengajar seluruh kelas. Bagaimana jika mengatur jadwal pelajaran dalam sejumlah kelas dengan sejumlah mata pelajaran yang akan diampu oleh sejumlah guru yang ada. Kendala inilah yang akan dicari jalan terbaik dengan menggunakan metode perhitungan Algortima Genetika.

Constraint Ada beberapa persyaratan (constraint) dalam mengatur penjadwalan mengajar. Constraint ini adalah sebuah syarat yang akan dipenuhi ketika menimbulkan susunan penjadwalan yang baik. Beberapa constraint tersebut, yaitu:

a. guru tidak boleh mengajar di jam yang sama kecuali mata pelajaran olahraga.

b. Guru sudah di tetapkan mengajar di mata pelajaran tertentu.

c. Jam mengajar dimaksimalkan adalah 8 jam per hari.

d. Satu jam pelajaran adalah 40 menit.

Parameter yang dapat dipakai pada perhitungan algoritma genetika yaitu:

a. Fungsi fitness atau fungsi tujuan akan dimiliki oleh beberapa calon penjadwalan untuk memilih tingkat fitness individu ini dengan kriteria yang hendak dicapai. b. komunitas jumlah individu yang akan dilibatkan pada semua tim atau tingkat melalui proses seleksi.

c. peluang terjadinya persilangan (crossover) pada suatu tim atau tingkat.

d. Peluang terjadinya mutasi pada setiap perorangan.

Adapun teori-teori yang diterapkan dalam sistem ini adalah:

Seleksi Operasi: seleksi yang akan digunakan dengan memperhatikan fitness atau tujuan dari tiap orang, generasi atau tingkat manakah yang dapat dipergunakan untuk masa selanjutnya. Seleksi ini juga dilakukan untuk mendapatkan calon bibit utama yang baik, semakin kecil nilai tujuannya maka semakin kecil juga

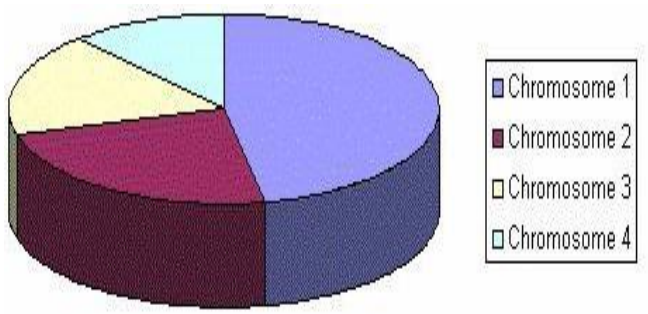

Gambar 3 Chromosome

Mutasi adalah suatu operator yang sangat penting dalam perhitungan algoritma genetika selain crossover. Metode dan tipe mutasi ini yang digunakan dalam encoding dan kendala yang diangkat. Berdasarkan encodingnya ini diantaranya adalah sebagai berikut: Permutation Encoding Memilih dua nilai dari gen dan menukarnya.

Contoh: $(12345678)$ )> ( 163459 278 )

Operator mutasi telah ini diciptakan untuk representasi permutasi, seperti metode insertion mutation. Insertion Mutation dapat menampilkan sebuah gen dengan cara acak dan dapat memasukkan ke kromosom dengan secara acak pula. 
e. Kawin Silang (Crossover)

Kawin silang (crossover) adalah salah satu operator penting dalam perhitungan algoritma genetika, metode dan tipe crossover yang akan dilakukan tergantung dari encoding dan kendala yang diangkat. Cara yang bisa dilaukan untuk menggunakan crossover sesuai dengan encodingnya yang dijelaskan sebagai berikut: Permutation Encoding dapat Memilih satu titik tertentu, nilai permutasi sampai titik crossover pada induk pertama dilakukan sebagai sisanya lalu dilakukan scan terlebih dahulu, jika nilai permutasi pada induk kedua belum ada pada offspring nilai tersebut akan ditambahkan.

Contoh: $(12345678)+(453689721)=$ 123456978

Nilai Fitness Kemudian dapat merancang sebuah kromosom (kandidat solusi/penjadwalan), langkah berikutnya adalah ketentuan fungsi fitness. Fungsi fitness yang akan berguna untuk memilah nilai sebuah kromosom. Nilai inilah yang akan nantinya dilakukan untuk menentukan apakah kromosom ini merupakan termasuk solusi terbaik atau solusi yang lebih baik dari kromosom lainnya. Beberapa definisi yang akan berkaitan dalam penghitungan nilai fitness atau nilai tujuan dapat dilihat pada

\begin{tabular}{|c|c|c|c|c|c|c|}
\hline \multirow[t]{2}{*}{ no } & \multirow[t]{2}{*}{ Nama guru } & \multirow[t]{2}{*}{ pelajaran } & \multicolumn{3}{|c|}{$\begin{array}{c}\text { Jam per } \\
\text { kelas }\end{array}$} & \multirow[t]{2}{*}{$\begin{array}{l}\text { Jumlah } \\
\text { wakty }\end{array}$} \\
\hline & & & $\mathrm{X}$ & $\mathrm{XI}$ & XII & \\
\hline 1 & mustika & $\begin{array}{l}\text { BK } \\
\text { Agama }\end{array}$ & 10 & 14 & & 24 \\
\hline 2 & agus & $\begin{array}{l}\text { DKK2 KK-5,KK } \\
\text { KKPI }\end{array}$ & 16 & 8 & & 24 \\
\hline 3 & setiawan & $\begin{array}{l}\text { DKK1 KKPI } \\
\text { KK } 2,6\end{array}$ & 14 & & 10 & 24 \\
\hline 4 & eka & $\begin{array}{l}\text { DKK3,KK-4,7 } \\
\text { KKPI }\end{array}$ & & 6 & 18 & 24 \\
\hline 5 & Putu suaba & $\begin{array}{l}\text { KK3,KK4 } \\
\text { KK5 }\end{array}$ & 14 & 10 & & 24 \\
\hline 6 & sandi & $\begin{array}{l}\text { DKK4, KK5 } \\
\text { KK7 }\end{array}$ & 16 & & 8 & 24 \\
\hline 7 & bacowati & $\begin{array}{l}\text { KK3 } \\
\text { DKK1 }\end{array}$ & 12 & 12 & & 24 \\
\hline 8 & Pebiasari & $\begin{array}{l}\text { DKK3, KK1 } \\
\text { KK6 }\end{array}$ & 16 & 8 & & 24 \\
\hline 9 & Sri paovati & $\begin{array}{l}\text { KK4, KK8 } \\
\text { DKK2 }\end{array}$ & 10 & & 14 & 24 \\
\hline 10 & sumarta & $\begin{array}{l}\text { IPS } \\
\text { PPKN } \\
\end{array}$ & & 16 & 8 & 24 \\
\hline 11 & mertavasa & PPKN & & 24 & & 24 \\
\hline 12 & sumarni & kewirausahan & & & 24 & 24 \\
\hline 13 & zulkifli & $\begin{array}{l}\text { Seni budava } \\
\text { PPKN }\end{array}$ & & 8 & 16 & 24 \\
\hline 14 & darma & kewirausahan & & & 24 & 24 \\
\hline 15 & andika & Bhsinggris & 24 & & & 24 \\
\hline 16 & Yuli astuti & matematika & & 24 & & 24 \\
\hline 17 & Dewi putri & matematika & & 24 & & 24 \\
\hline 18 & Eka sumaroi & matematika & & 24 & & 24 \\
\hline 19 & Wirxa butra & Bossinggris, & 24 & & & 24 \\
\hline 20 & juliani & Bhs.inggris, & 24 & & & 24 \\
\hline 21 & Buspawati & IPA & & & 24 & 24 \\
\hline 22 & m,agus & $\begin{array}{l}\text { Seni budava } \\
\text { IPA }\end{array}$ & & & $\begin{array}{l}12 \\
12 \\
\end{array}$ & 24 \\
\hline 23 & melina & Bhs.jepang & & 24 & & 24 \\
\hline 24 & mataram & $\begin{array}{l}\text { Kimia } \\
\text { Fisika } \\
\end{array}$ & & 12 & 12 & 24 \\
\hline 25 & suxuiji & IPS & & & 24 & 24 \\
\hline 26 & Desi pusba & $\begin{array}{l}\text { BK } \\
\text { agama }\end{array}$ & 12 & 12 & & 24 \\
\hline
\end{tabular}

Gambar 5 Jadwal

Untuk mendapatkan nilai rata-rata, kita harus menjumlahkan jam pelajaran guru dalam seminggu. Berikut cara menghitungnya;

$=24+24+24+24+24+24+24+24+24+24$

$+24+24+24+24+24+24+24+24+24+24$

$+24+24+24+24+24+24+24+24+24$

$=696$

$=696 / 29$

$=24$

Berikut ini akan ada contoh perhitungan nilai fitness function pada sebuah kromosom sampel 
$(24-24)^{2}+(24-24)^{2}+(24-24)^{2}+(24-$

$24)^{2+}(24-24)^{2}+(24-24)^{2}$

$(24-24)^{2}+(24-24)^{2}+(24-24)^{2}+(24-$

$24)^{2+}(24-24)^{2}+(24-24)^{2}$

$(24-24)^{2}+(24-24)^{2}+(24-24)^{2}+(24-$

$24)^{2+}(24-24)^{2}+(24-24)^{2}$

$(24-24)^{2}+(24-24)^{2}+(24-24)^{2}+(24-$

$24)^{2+}(24-24)^{2}+(24-24)^{2}$

$(24-24)^{2}+(24-24)^{2}+(24-24)^{2}+(24-$

$24)^{2+}(24-24)^{2}$

dengan melakukan standar deviasi.

Dimana X jumlah jam mengajar dalam satu minggu dikurangi $M$ rata-rata jam mengajar dibagi $\mathrm{N}$ dengan jumlah guru dan dikurangi nilai 1 . Maka nilai fitness adalah.

$$
\begin{aligned}
& =0+0+0+0+0+0+0+0+0+0+0+0+0+0+0+ \\
& 0+0+0+0+0+0+0+0+0+0+0+0+0+0=0= \\
& 0=0 / 29=0
\end{aligned}
$$

Maka nilai fitnesnya adalah 0 berdasarkan standar deviasi

\section{KESIMPULAN}

Penjadwalan pembelajaran merupakan suatu hal yang sangat penting, kegitan ini termasuk dalam sebuah proses mengajar. Untuk membuat jadwal pelajaran tidaklah mudah kita harus melihat dari berbagai aspek yang dapat mempengaruhi penjadwalan tersebut. Dalam pembuatan penjadwalan pelajaran ini kita harus memilah guru berdasarkan keahliannya dan untuk menentukan waktunya kita harus memperhatikan pelajaran yang lain apakah terdapat tumpukan pelajaran sebelumnya kepada siswa. Berdasarkan penelitian diatas maka dapat diambil kesimpulan sebagai berikut:

a). Pada pembuatan jadwal mengajar ini lebih baik dan tepat menggunakan algoritma genetika daripada dengan cara manual.

b). Dalam penelitian ini mendapatkan suatu perhitungan yang memerlukan metode algoritma genetika dalam jadwal mengajar di sekolah tersebut.

c). Metode ini dapat mengimplemtasikan sebagai developer atau pengembang untuk menjalankan system-nya dalam hal penjadwalan mengajar.

\section{DAFTAR PUSTAKA}

Andhyka, A. (2018). Penerapan Algoritma Genetika Pada Permasalahan Matematika. SYSTEMIC, ISSN: 2460-8092, vol.4 no.01.

Elva, Y. (2019). Sistem Penjadwalan Mata Pelajaran Menggunakan Algoritma Genetika. Jurnal Teknologi Informasi, P-ISSN:2580-7927 E-ISSN:26152738, vol.3 no. 1 .

Kevin Krisnandi1, h. a. (2017). Implementasi Algoritma Genetika untuk Memprediksi Waktu dan Biaya Pengerjaan Proyek Konstruksi . PISSN:2085-4315 E-ISSN:2502-8332, JURNAL ILMIAH FIFO, vol.IX no.2.

Sugeha, I. H. (2019). Optimasi Penjadwalan Menggunakan Metode Algoritma Genetika Pada Proyek Rehabilitas Puskesmas Minangga. ISSN: 2337-6732 Jurnal Sipil Statik, vol.7 no. 12 .

Syafrial Fachri Pane1, R. M. (2019). Implementasi Algoritma Genetika Untuk Optimalisasi Pelayanan Kependudukan. ISSN: 1907-4964, Jurnal Tekno Insentif, vol.13, no.2.

Hajis Setiawan, D. R. (2012). Penerapan Algoritma Genetika Pada Software Penjadwalan Mata Pelajaran (Studi Kasus: SMPK KARITAS 2 Surabaya). 14. 
cusnah puteri damayanti, r. r. (2017). Implementasi Algoritma Genetika Untuk Penjadwalan Customer Servis (Studi Kasus: Biro Perjalanan Kangoro). Jurnal Pengembangan Teknologi Informasi dan Ilmu Komputer, ISSN: 2548-964X. vol.1 no.6. 10. 